\title{
Ideological Battle of Socialist Realism Against The Ideology of Feudalism Religious in Novels of Pramoedya Ananta Toer Study of Hegemony Gramscian
}

\author{
Moh. Muzakka, Mirya Anggrahini \\ \{muzakkamoh@yahoo.co.id\} \\ Department of Indonesian Literature, Faculty of Humanities, Diponegoro University \\ Jl. Prof. Soedarto, S.H. Undip Tembalang, Semarang, Central Java - Indonesia, 50275
}

\begin{abstract}
Literary works are a means for authors to offer various ideologies to their readers. Through literature, the author can influence the views of life or the reader ideology. This short article intends to reveal the ideological struggle in the novel Gadis Pantai and the novel Midah Simanis Bergigi Emas by Pramoedya Ananta Toer using the analysis of Gramsci's hegemony. The results of the analysis show that the novel Gadis Pantai and novel Midah Simanis Bergigi Emas offers three ideologies namely the ideology of feudalism (which controls), the primitive ideology of coastal culture (which is mastered), and the ideology of socialist realism (which is championed). As the two contrasting cultures in the novel are seen as an unfavorable culture, the culture of socialist realism is the most ideal according to the author.
\end{abstract}

Keywords: Coastal; Hegemony; Ideology: Priyayi; Socialist Realism.

\section{Introduction}

Literary work is a tool to fight for a particular ideology, namely the ideology that is understood and believed by the author. The emergence of conflicts that build literary works is more a battle between the dominant ideologies with the hegemonic ideology chosen by the author. The appearance of the ideology that is fought for is caused by awareness or a clash between sedimentary ideologies and the dominant or powerful ideologies. Regarding the issue, Mussaif (2018: 69) revealed that the fight of ideological in literary works needs to be studied more deeply.

The author's ideology is influenced by the author's educational background, religion, ethnicity, language, mass organizations, and political organizations. Even, this ideological similarity can be joined in groups of authors. Such conditions have occurred in the history of Indonesian literature. The presence of groups of arts and cultural institutions such as LKN, Lesbumi, and Lekra at the beginning of the independence of the Republic of Indonesia is a proof of the existence of groups of authors who are united in the certain school or understanding or even political parties.

One of the influential and most consistent figures of Lekra, with the understanding of socialist realism, is Pramoedya Ananta Toer. In addition to his commitment to his institution and his strong belief in the understanding he followed, even though his life was spent in prison in the Sukarno and Soeharto regimes, he did not stop writing novels (2018: 68-69). 
In most of his works, Pramoedya Ananta Toer offers an ideology of socialist realism which he thinks is the most ideal for society. In the novels he created, he always showed that socialist realism was better than other ideologies, both feudalist, capitalist, and faith-based ideologies. Because, according to him, the ideology of socialist realism imposes equal humanity in social classes, including gender (cf. Mussaif, 2014; Mussaif, 2018).

Starting from these thoughts, the researchers wanted to reveal the ideological landscape in two novels by Pramoedya Ananta Toer which are not his main novels. The novels are Gadis Pantai and Midah Simanis Bergigi Emas. The novel will be examined using a sociological approach to literature, specifically the perspective of Gramsci's hegemony. The reason is that Gramsci considers that the world of ideas is not only an expression of class structure (infrastructure) that is material but becomes one of the strengths of the material itself (Faruk, 1994: 61).

Literary work is a world of ideas written by authors who live in a certain era and place. As a complex social person, automatically, the ideas are expressed in the form of the work are strongly influenced by the ideology that is followed or believed. Gramsci considers that the world of ideas, culture, superstructures are not only a reflection or expression of a class structure that is becomes one of the strengths of the material itself (Faruk, 1994: 61-62).

In line with Gramsci, Raymond William asserted that hegemony is a process, not a form of domination that exists passively, but something that must be constantly updated, recreated, maintained, and modified. He said that ideology in the literature can be categorized into three, namely the dominant ideology; risen ideologies; and residual ideologies that existed before being dominated by dominant ideologies (Faruk, 1994: 78-79).

\section{Method}

The material object of this study is two novels of Pramoedya Ananta Toer's titled Gadis Pantai and Midah Simanis Bergigi Emas, with its formal object is the ideological issues in both the novel. The study perspective is based on the sociological approach of literature, namely an approach that focuses on the relationship of literary work with social values that apply to authors and readers (Damono, $2010 \mathrm{cf}$. Faruk, 1995). Because this research only focuses on literary works, this research is classified as library research. After the data is collected, the data are analyzed carefully using the sociological approach of literature (Wellek and Warren, 1990; Faruk, 1995; Ratna, 2004; Damono, 2010).

\section{Results and Discussion}

\subsection{Primitive Ideology: Culturalism}

The primitive ideology that appears in the novel Gadis Pantai is the ideology of culturalism, which is an ideology that has lasted for generations. Because the figure of Gadis Pantai lives in the coastal community, the prevailing cultural ideology tends to be egalitarian, transparent, the language tends to be rude and likes to help each other. On the other hand, the culture that applies to Bendoro's character is very different. He was born from the priyayi-santri class. The underlying primitive ideology is feudalism, individualism, and elitism with the use of subtle language as applicable to palace culture.

The primitive ideology that appears in the Midah Simanis Bergigi Emas novel is the ideology of Javanese-santri culturalism, which is an ideology that has lasted for generations. In accordance with the names of the novels namely Midah, Haji Abdul, Riah, Ahmad, Rodjali are culturally names that have an Islamic background that lives on Java. Such a culture of 
society is commonly called the Javanese-santri faction. The Javanese-santri term here refers to the figures who embraced Islam, obeyed worship, and even songs that were played every day in Arabic songs. The family of the main character is classified as high social status and very religious. However, the character's nature changes when Midah has a younger brother. At first, his father, Haji Abdul, is very fond and pampering Midah. After the presence of the boy, her father becomes very fond of the boy and does not pay attention to Midah. Even when Midah acts rebellious such as going out until late, she does not get noticed.

This patriarchal culture is built by a down-to-earth Javanese culture coupled with religious dogma which is seen to be siding with patriarchy. It is in this Midah Simanis Bergigi Emas novel that Pramoedya strikes a cultural ideology and feudal ideology that is considered to be less ideal at the level of social life.

\subsection{Dominant Ideology: Feudalism}

The dominant ideology in the novel Gadis Pantai is Feudalism. This ideology is voiced and played by a duchy of Rembang called Bendoro. He has power over the "Palace" and his working area. According to the rules of the royal system (absolute monarchy) that applies, a king (read: aristocrat/leader), especially those who are a chief of an area (e.g. Duke/regent), must be authoritative in front of the community which they lead. He must have more skills than the community he leads. These skills are the skill of intelligence (higher education), managerial skill, spiritual skill, and physical ability (kanuragan).

Related to the problem of skilled leaders over the people it is an inevitability. However, with the skills over the people, the leader feels powerful over his people so that the relationship between the leader and his people changes into a relationship: the smart and the ignorant, the priyayi and those who are servants, as well as those who are powerful and who are controlled. This is what later, culturally and genealogically, fosters feudalism and authoritarianism in the state system (kingdom).

In the novel Gadis Pantai, Pramoedya Ananta Toer explicitly describes feudalism and authoritarianism as the dominant ideology in the system of government (priyayi) in Java. Through the priyayi (Bendoro) figures who were clever, pious, rich, and powerful, Pramoedya showed that the priyayi were displayed as "haunted" and very powerful over their people. This figure occupies a high social class as well as the position of the boss and his workers.

This position is so high, it becomes increasingly strong and dominant when the priyayi figure is displayed in a religious and spiritual force. The reason is that Pramoedya completes the priyayi figure with the character of a religious santri such as knowledge and good deeds of Islam. Priyayi was described as a person who diligently prayed, recited, loved charity, taught religion, and even mentioned doing hajj twice.

The appearance of the priyayi figure wrapped in religious santri in this novel is always displayed as an antagonist, that is a figure who adheres to feudalism and authoritarianism. This figure is shown as a figure who must be worshiped and praised and must be followed. In managerial terms, the priyayi figure is described as a very authoritarian figure.

The dominant ideology in the Midah Simanis Bergigi Emas novel is feudalismreligious. This ideology is voiced and played by Haji Abdul, a Javanese ethnic shopkeeper who is devoted to worship. He is the head of the family who is always praying, love family and obey worship. As a family leader, he also regulates the family which are his wife and child according to the culture and understanding of the religion he adheres to.

In the novel, the figure of Haji Abdul is described as an unfair and authoritarian person in leading the family. This character's injustice is apparent after he has a son. Midah, who is initially very loved and pampered and educated in Javanese-religious nuances, are not cared 
for and tend to be left alone. Even though Midah violates the rules like going out of the house and coming home late at night, her father does not care.

The character's unfair attitude resulted in an authoritarian attitude that increasingly strengthened the repression of female leaders in his family. Using religious dogma, as a patriarchal leader, Haji Abdul became a very strict family head. All family members must follow their wishes and orders.

The authoritarian attitude of the patriarchy can be seen in the character of Haji Abdul in arranging and marrying his daughter, Midah, with a man who is unknown and dear to her. In this novel, Midah is matched with a middle-aged, wealthy people, has hajj title, and many wives. This father's authoritarian attitude is clearly demonstrated in this novel. Midah, as a child who is obedient and afraid of her father, she cannot resist it. She obeys her father's orders, married Haji Terbus of Cibatok who is not single and has many wives.

\subsection{Awaken Ideology: Socialist Realism}

In an effort to arouse the ideology of socialist realism, Pramoedya Ananta Toer voiced it through marginal figures, children of poor fishermen, uneducated, namely Gadis Pantai. The girl featured in the novel is originally a young girl who is still innocent and childish. After being married to a Bendoro who he had never seen or known, she is escorted by the family and the head of her village to the Bendoro "palace" in Rembang.

Arriving in the "palace" environment, Gadis Pantai seems to be alienated from the rules and systems of manners that apply in the priyayi-santri world. She cannot immediately meet with her husband, but she has to be educated and dressed first by a maid. She has to learn the dress codes, manners, how to talk, how to eat and drink, and other small aristocrat things she has never gotten in her village. Faced with the problem that greatly restrained her, Gadis Pantai is aware of her position. Although she becomes a primary woman of a Bendoro, she is nothing more than a slave who must always serve her master. Likewise in matters of property, family, decision making, and sex issues, she must follow Bendoro's wishes. Gadis Pantai considers the aristocrat world to be biased, unjust and looking down on the common people. Seeing this imbalance, Gadis Pantai rebelled against feudalist and autocratic priyayi.

Not much different from the novel Gadis Pantai, the novel Midah Simanis Bergigi Emas is also the same. In an effort to arouse the ideology of socialist realism, Pramoedya Ananta Toer voiced it through figures who lived among Javanese santri families, the children of a devout pilgrim, namely Midah. The girl featured in the novels initially very loved by her father and mother, Haji Abdul and his wife. Changes in the attitude of parents to her begin when she is nine years old and has a younger brother, she is not cared for and even tends to be left alone. Because she feels left behind, she fights in her own way like going out, going home late at night, and to learn to sing Keroncong songs. Even though her father forbade him, she still enjoyed and loved Javanese ethnic songs influenced by Europe.

Opposition to the authoritarian attitude of the patriarchy also appears in the attitude of Midah to a husband whom she doesn't like from the start. After having one child, she leaves his husband's home with her child to seek freedom. She does not return to her parents' house but seeks her own life as a street singer and Keroncong singer.

Through this Midah Simanis Bergigi Emas novel, the author clearly stands for the ideology of socialist realism and sees it as the ideal ideology. In this novel, the author shows that the dominant ideology which is very negative religious feudalism because the ideology represses women in unfair and authoritarian ways. 


\section{Conclusions}

From the analysis of Gramscian hegemony on the novel, it can be concluded that the two novels reveal three contrasting ideologies, namely the cultural ideology that is dominated (common people, women), the dominant ideology that controls (priyayi santri culture), and the ideology that is fought for (socialist realism). Because the cultural feudalism and religious feudalism in this novel are described not as ideal cultures, the authors offer the best ideology that is the ideology of socialist realism because it promotes equality and rejects feudalism.

\section{References}

[1] Damono, Sapardi Djoko. 2010. Sociology of Literature: Brief Introduction (new edition). Ciputat: Editum.

[2] Faruk HT. 1994. Sociology of Literature An Introduction. Yogyakarta: Student Library.

[3] Mussaif, Moh. Muzakka. 2014. "Pramoedya Ananta Toer's views on Priyayi Santri: The Study of Sociology of Literature on Coastal Girl Novels. In the Proceedings of the PIBSI International Seminar XXXVI "Building the Image of Indonesia in the International Eye through Indonesian Language and Literature" was held by the University of Ahmad Dahlan University in Yogyakarta.

[4] Mussaif, Moh. Muzakka. 2017. "Novel of the Beach Girl by Pramoedya Ananta Toer: Analysis of Hegemony". In Alayasastra Journal Volume 13, Number 1, May 2017.

[5] Mussaif, M. Muzakka. 2018. This is Researching Literature. Semarang: SINT Publishing.

[6] Muzakka, M., Suyanto, M. Hermintoyo. 2016. "Representation of Gender Relations in Indonesian in Novels from the 1960s to the 2000s: Analysis of Feminist Critical Discourse". Research Report of the Ministry of Research, Technology and Higher Education DRPM.

[7] Toer, Pramoedya Ananta. 2011. Beach girl. (7th print). Jakarta: Dipantara Lantern.

[8] Ratna, Nyoman Kutha. 2004. Theory, Methods, and Literary Research Techniques. Yogyakarta: Student Library.

[9] Siminto. 2008. "The novel by Pantai Pramoedya Ananta Toer: Levi-Straus Structural Analysis". In the Journal of the Study of Religion and Society . Vol. 5, No.1. June 2008.

[10] Wellek, Rene and Austin Warren. 1990. Literary Theory. (Indonesianized by Melani Budianta). Jakarta: Gramedia. 